plans for a coast survey were adopted, and he was appointed to start the work. There was, however, much delay. Having during 1807-9 held a chair of mathematics at West Point Military Academy and during 1809-11 a chair of natural philosophy, in the latter year he was sent by the Treasury to England to purchase instruments. Owing to the War of 1812 between Great Britain and the United States, it was three years before he was able to return to America. The survey was actually started under Hassler's superintendentship in 1816, but two years later he was deprived of his post owing to new regulations which allowed only naval and military officers to be employed. During 1819 he was astronomer to the party sent to settle the north-eastern boundary, but then he was thrown completely on his own resources. For ten years he farmed, somewhat unsuccessfully, in New York State, taught and wrote mathematical text-books. For a time, too, he was employed at the New York Custom House, and then in 1832 when the Survey was reorganized-its work had been practically suspended-he once again became its superintendent. Though sixty-two years of age, he entered upon his work with enthusiasm, assembling the necessary instruments, training assistants and commencing operations in the field. In this work he was engaged until his death at the age of seventythree at Philadelphia.

Hassler's memory was honoured at the centennial commemoration of the Survey, and in 1929, Prof. Florian Cajori, the historian of science, of the University of California, published his biography under the title "The Chequered Career of Ferdinand Rudolph Hassler". In spite of many troubles-domestic, financial and administrative-Hassler left his mark, and it has been said that "Time has justified the soundness of his ideas", and that "the extension of the survey of the coast to the present day follows his plan, and the field work he carried out more than a century ago is of such high precision that it still forms part of the basic network". As State after State was added to the country, so the work of the Survey extended. Under Hassler's successor, Alexander Bache, the electric telegraph was used in the determination of longitude, and under the third superintendent, Benjamin Peirce, the triangulation was carried from the Atlantic to the Pacific. In the nineteenth century the Survey was responsible for the standard weights and measures; but in 1901 a new department was founded for this work under the title of the United States Bureau of Standards. The centennial celebrations referred to were held in Washington under the presidency of the superintendent, Mr. E. Lester Jones, the President of the United States, Mr. Woodrow Wilson, being among the speakers. A memorial volume was issued, and this contains a portrait of Hassler.

\section{Wellcome Veterinary Research Station}

The Wellcome Foundation has acquired Ely Grange Estate, Frant, Sussex, for the purpose of extending the veterinary research now carried on at the Wellcome Physiological Research Laboratories, Beckenham, Kent. The need for accommodation where experiments can be carried out on farm animals has been felt for some time. The estate will be known as the Wellcome Veterinary Research Station and the resident veterinary surgeon will be Mr. S. L. Hignett, who will be responsible to Dr. R. F. Montgomerie, veterinary research director at the Wellcome
Physiological Research Laboratories, where veterinary research, particularly on the laboratory side, will be continued. The full development of the Station at Frant will be delayed until after the War, as the mansion, which will be converted eventually into laboratories, is requisitioned by the Government; but the extensive and modern farm buildings will be occupied and used at once. A start has been made by the acquisition of a herd of pedigree Ayrshire cattle. In addition to the main purpose of the Station, there will be accommodation for the breed. ing of laboratory animals on a large scale. It is hoped to establish a number of pure lines for this purpose and to do work on genetics in connexion with the breeding of these animals.

\section{Post-War Needs of Universities in Great Britain}

Sir JoHn ANDERSon recently stated in answer to a question in the House of Commons that the constitution of the University Grants Committee has been under consideration for some time, and he hopes very shortly to announce the appointment to the committee of a number of new members. As regards the equipment of universities to deal with the post-war situation, the universities themselves have been studying the various problems which will face them after the War. The Committee of Vice-Chancellors and Principals has asked the University Grants Committee to undertake a review of these problems in order to form a considered estimate of the need for increased assistance from the Exchequer. This request will require to be considered as a matter of urgency by the reconstituted Committee; meantime, the universities are being asked to formulate their post-war needs so far as they can be estimated in present circumstances.

\section{Replacement of British Museum's Foreign Books}

A GENERous offer to replace, so far as possible, the many volumes in the section of non-English books and periodicals which have been destroyed by enemy action in the British Museum has been made by the Allied Governments in London. The offer was put forward by Dr. Philip Argenti, honorary attaché to the Greek Embassy, at a recent meeting of the Books and Periodicals Commission of the Conference of Allied Ministers of Education. Representatives of the Allied Nations pledged their governments to replace, after the War, as a gift, to the best of their abilities, the periodicals and books in their respective languages damaged or destroyed by air attack. The Museum has been invited to submit a list of such periodicals and books to the Commission, classified according to their languages.

\section{The Newcomen Society}

The Newcomen Society met for its annual general meeting on Novernber 10 at the Northampton Institute, London, when the report of the Council for the past year was submitted, and the election of officers took place. The Society has continued to expand, and on September 30 the membership stood at 3,092, irrespective of fifty-five libraries which receive its publications. Owing to the very large increase in membership in North America, the rules of the Society have been amended so that branches overseas can elect their own members and manage their own finances, thus avoiding unnecessary correspondence and expense. The subscription has 